\title{
Research Article \\ Combining ability analysis of three line hybrids in rice (Oryza sativa L.) under aerobic condition
}

\author{
R. SATHYA AND S. JEBARAJ
}

\begin{abstract}
SUMMARY
Information on the availability of genetic variability and mode of gene action are critically important for choosing effective breeding methods that result in appreciable improvement in performance under drought stress. An investigation in rice (Oryza sativa L.) was carried out subjecting six 'lines' and 15 'testers' crossed in a line $\times$ tester mating design and the 90 hybrids along with 21 parents were tested for gene action, combining ability for 19 traits under aerobic condition. Three 'lines' viz., IR79128A ( $\left.\mathrm{L}_{1}\right)$, IR79156A $\left(\mathrm{L}_{2}\right)$ and IR70369A $\left(\mathrm{L}_{4}\right)$ and three 'testers' viz., IR7925A-428-2-1-1R (T $)$, KMP -148 $\left(\mathrm{T}_{12}\right)$ and BI-33 $\left(\mathrm{T}_{15}\right)$ were identified as the best general combiners. The genotype IR70369A is suggested for conversion to cytoplasmic male sterility with suitable male sterile source. The parents MAS -26, IR 7925A-428-2-1-1R and KMP-105 are recommended for testing their restorability with suitable CMS source.
\end{abstract}

Key Words : Additive genetic variance $\left(\sigma^{2} \mathrm{~A}\right)$, Dominance genetic variance $\left(\sigma^{2} \mathrm{D}\right)$, General combining ability variance/ effects, Specific combining ability variance/effects, Aerobic rice

\footnotetext{
How to cite this article : Sathya, R. and Jebaraj, S. (2015). Combining ability analysis of three line hybrids in rice (Oryza sativa L.) under aerobic condition. Internat. J. Plant Sci., 10 (2): 122-129.
}

Article chronicle : Received : 21.01.2015; Revised : 09.06.2015; Accepted : 18.06.2015

\section{MEMBERS OF THE RESEARCH FORUM •}

Author to be contacted :

R. SATHYA, Department of Plant Breeding and Genetics, Vanavarayar Institute of Agriculture, Manakkadavu, Pollachi, COIMBATORE (T.N.) INDIA

Email: sathyapbg@gmail.com

Address of the Co-authors:

S. JEBARAJ, Department of Plant Breeding and Genetics, Agricultural College and Research Institute, MADURAI (T.N.) INDIA 